\title{
Thermal Performance of a Single Slope Solar Water Still with Enhanced Solar Heating System
}

\author{
Abdullah M. Al Shabibi and M. Tahat \\ Department of Mechanical and Industrial Engineering \\ Sultan Qaboos University - P.O. Box 33, Al Khoud123 (Oman) \\ Fax number:+968 24141316, e-mail: ashabibi@squ.edu.om
}

\begin{abstract}
This paper investigates experimentally the thermal performance of conventional solar water still with enhanced solar heating system. A number of variables have been considered including the water depth inside the still and the inlet saline water temperature to the solar still from the preheater solar collector system and the still basin geometry. The still is modified to include preheating solar system, to preheat saline water before entering the solar still, in order to enhance its hourly or daily yield of pure water. A single slope conventional solar still with solar preheating unit was constructed and experimentally tested under different weather conditions. Different quantities of water in the solar still basin were tested to find the effect of water quantity on the hourly yield and still's thermal efficiency.

It was found that $1 \mathrm{~cm}$ depth and finned still basin gives the best performance in terms of fresh water yield and thermal efficiency. The addition of the solar water preheater to the system has significantly increases the inlet basin saline water temperature to almost saturated temperature and saline water in the basin needed only small heat to be vaporized and hence increases the production of fresh water and enhances the solar still thermal efficiency.
\end{abstract}

\section{Key words}

Solar energy, solar desalination, single slope solar water still.

\section{Introduction}

Single slope water still simply consists of a thermally insulated box with a glass cover. The solar energy penetrates the glass and causes a greenhouse effect inside the box. The water inside the box heats up and evaporates leaving behind any impurities such as the salt. The water vapour then condensate when it contacts the inside glass cover. The condensated pure water can then be collected. Single slope still was studied both theoretically and experimentally by a number of researchers. Nafey at al. [1] investigated the effect of the solar radiation, wind speed, brine depth and glass tilting angle on still productivity. It was found that the solar radiation is the most affecting parameter on the productivity. The productivity decreases with the increase of the wind speed increases due to the decrease in the fractional energy of evaporation. Furthermore, when the brine depth was increased the productivity decreased. Moreover, it was found that in summer the tilt angle of the glass cover should be maintained as small as possible because the horizontal plane receive more radiation than the inclined plane does, while in winter the productivity increases when the inclination is increased. Solar still was tested in different climate conditions and in many places around the world. Singh and Tiwari [2] studied the monthly performance of passive and active solar stills for different Indian climate conditions. Medugu and Ndatuwong [3] designed and tested a solar still under actual environmental condition of Mubi, Nigeria. They developed theoretical analysis of heat and mass transfer mechanisms inside the still. They did experimental and theoretical investigation on the distillation performance of the solar still. They found that the instantaneous efficiency increases with the increase of the solar radiation and the feed water temperature. Hassanain and Abu-Zied [4] conducted a study about single slope solar still for sea water distillation. The investigation was carried out under the open environmental conditions of Egypt on a single slope still inclined by $20 \%$. The investigation addressed the following: The still productivity, distilled water salinity and still performance in term of the still efficiency and the coefficient of performance. They found that the still productivity and efficiency increases by increasing the solar radiation. The highest productivity was $0.226 \mathrm{~L} / \mathrm{m} 2$ obtained during the month of July. Also, they found that the still performance increases gradually from the sunrise time till it reaches certain maximum value at noon and afternoon by about an hour respectively and then decreases until it reaches minimum value at sunrise time. Arjunan et al. [5] conducted an experimental study on solar still with sponge liner. Two types of measurements were performed for the same climatic conditions: one with the sponge sheet placed on the inner wall surfaces (the back and the side wall) and one without the sponge sheet. It was found that the productivity of the solar still was $15 \%$ higher than the conventional still. They also found that decreasing the water depth increases the productivity of the still. Afrand et al. [6] carried out a theoretical study of solar distillation in a single basin under the open environmental condition of Chabahar Iran. In this research, they were investigating the still 
productivity, distilled water salinity and still performance in term of the still efficiency. They found that the maximum efficiency of the solar still was at noon due to the high radiation. Another study about single solar still was conducted in India by Prasad et al. [7]. The still was modified with graphite powder to maximize the absorptivity. In this study, the effect of four parameters was investigated; the amount of silicate, amount of acid, amount of graphite powder and water depth. The maximum productivity of the still was $1.6 \mathrm{~L} / \mathrm{m} 2$. It was found that the productivity of the solar still decreases as the amount of water is increased. When the amount of sodium silicate is increased the productivity increases, but when more than $150 \mathrm{~g}$ was added the productivity decreased. The same result was obtained when increasing the amount of graphite and acid. The peak performance was obtained by $150 \mathrm{~g}$ of sodium silicate, $100 \mathrm{ml}$ of $2 \mathrm{NHCl}$, and $50 \mathrm{~g}$ of graphite.

The main aim of the present work is to design and test a single slope water still with pre-solar water heating system in order to investigate the effect of the amount of water in the basin, the inlet water temperature to the basin from the pre-solar water heater on the amount of fresh water yield and on its thermal performance, and the still basin geometry (flat, finned and corrugated surface).

\section{2. $\quad$ Test Rig}

A single slope solar water still with solar preheater system was designed and fabricated. The still consisted mainly of a base unit, made from galvanized steel, and a glass cover. The surface area of the still is 1 square meter. The bottom inner surface of the base unit is painted black and the inner side walls are painted white. The side walls of the base unit are insulated from outside with Styrofoam. At the bottom end of the inclined surface of the base unit, a passage is made to collect the fresh water coming down of the cover glass. Three floating valves are attached to the back side of the still to allow the adjustment of the water depth inside the basin of the still (see figure 2). A simple solar collector was constructed and made of a single glass cover with water loop to preheat the salinity water before entering the still. The whole system, the still; the collector and the supply tank, was assembled as shown in figure 1.

\section{Experimental Procedure}

The experiments conducted to study the effect of water level in the basin and the effect of using solar preheater on the yielded fresh water and on the solar still thermal performance. Thermocouples were positioned at different locations in the still to measure the temperatures throughout the day. The thermocouples were connected to a data logger to record and save the temperatures readings every 15 minutes.

First, the solar collector was connected to the inlet of the solar still basin and the correct amount of salinity water was introduced into the basin. The basin inlet and the solar collector outlet temperatures were measured by thermocouples and recorded every 15 minutes in order to find the mean average hourly temperatures. The same procedure was followed for measuring the still water, the cover glass, the vapor and the ambient temperatures. The fresh water yield was collected and recorded using sealed graduated glass container on an hourly basis.

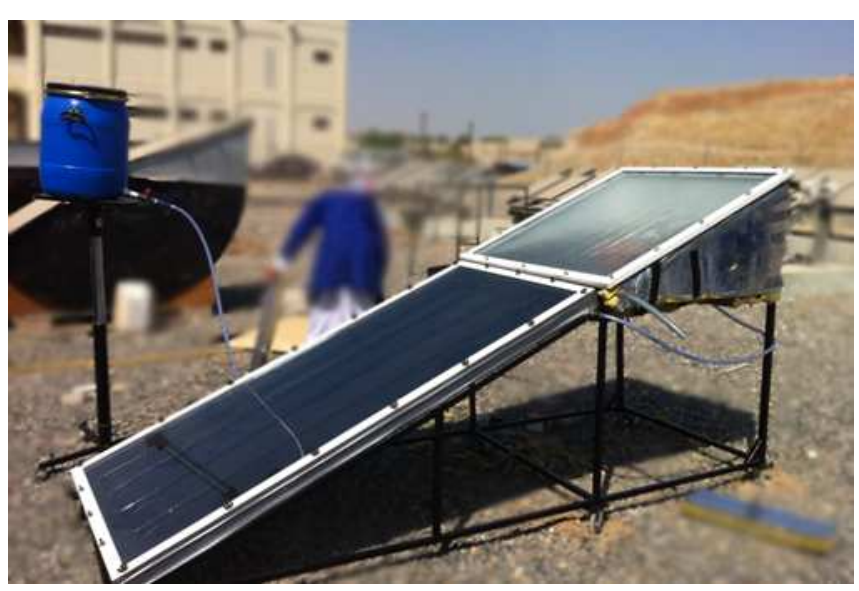

Fig. 1 Experimental set up of single slope solar water still with solar energy heating system

\section{Thermal Efficiency of the Water Still}

To assess the performance of the still, it is important to identify its thermal efficiency. The still efficiency can be calculated using the following formula

$$
\eta=\frac{\text { evaporation heat }}{\text { total input solar energy }}=\frac{\dot{Q}_{\text {evp }}}{\dot{Q}_{\text {in }}}
$$

The heat of vaporization can be calculated using the following formula

$$
\dot{Q}_{e v p}=\dot{m} h_{f g}
$$

Where $\dot{m}$ is the mass flow rate and $h_{f g}$ is the latent heat of vaporization. The energy input due to solar radiation can be calculated as

$$
\dot{Q}_{\text {in }}=\alpha \tau A_{p} I
$$

Where $\alpha, \tau, A_{p}$, and I are absorptivity coefficient, transmission coefficient of the glass cover, area of the absorbing plate and solar intensity on horizontal surface respectively.

\section{RESULTS}

The result of the experimental tests shows that the production rate of fresh water is directly related to the water level height in the basin and to the solar radiation. As the water level in the basin decreases and solar radiation increases the production rate increases. For finned bottom surface, the hourly accumulated fresh water for three different water depths are shown by figure 
2 and it shows that the depth of $1 \mathrm{~cm}$ depth outperform the $2 \mathrm{~cm}$ and $3 \mathrm{~cm}$ of water depth in the solar still basin. This is due to the small heat capacitance of the water at $1 \mathrm{~cm}$ depth compared with the other two depths and because it needs less energy to be vaporized. The maximum hourly amount of fresh water yield is at noon and the total hourly accumulated is about $1800 \mathrm{ml}$ per meter squared for water depth of $1 \mathrm{~cm}$.

The average efficiency is calculated over the testing time which lasted between 7 am and $5 \mathrm{pm}$ and it was found to be $61.9 \%$ for finned basin surface. The addition of the solar water preheater to the system has significantly increased the inlet basin saline water temperature to almost saturated temperature and saline water in the basin needed only small heat to be vaporized as shown in figure 3 . An increase of about $20 \%$ is noticed in the fresh water yield when finned surface was used in the still basin. Figure 4 shows the temperature readings obtained inside the still for flat and finned surface. Figure 5 shows the fresh water yield with and without using a solar preheater. An increase of about $50 \%$ in the yielded fresh water was found.

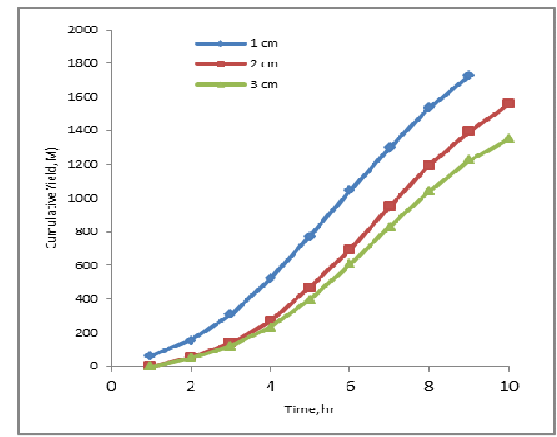

Fig. 2 Fresh water commulative yield for finned surface

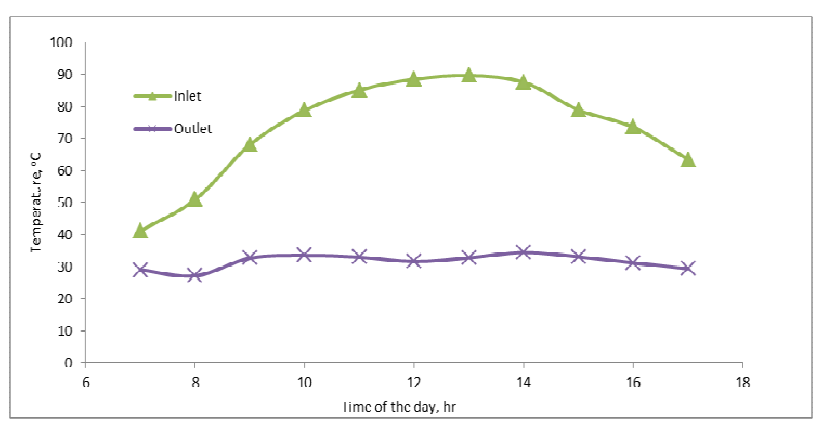

Fig3. temperature readings at the solar collector inlet and outlet

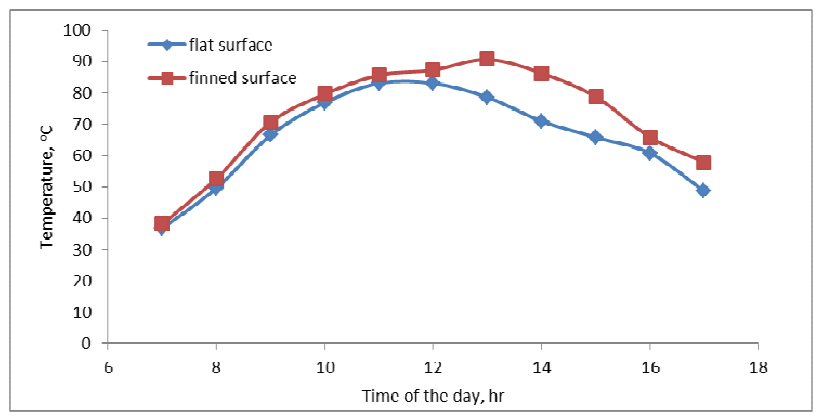

Fig. 4 Comparison of temperature readings inside the still for flat and finned surface

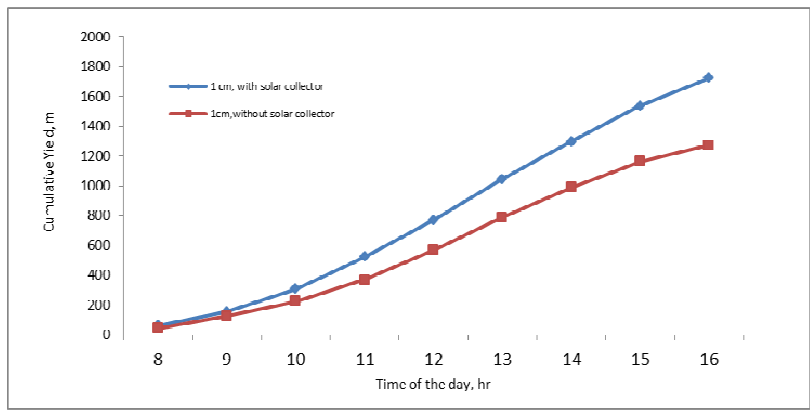

Fig. 5 Comparison of yielded fresh water hourly rate for still with and without solar preheating

\section{Conclusion}

This paper investigates the thermal performance of solar water still with enhanced solar heating system. A number of variables have been considered including the water depth inside the still and the inlet saline water temperature to the solar still from the preheater solar collector system. It was found that $1 \mathrm{~cm}$ depth gives the best performance in terms of fresh water yield and thermal efficiency. The addition of the solar water preheater to the system has significantly increased the inlet basin saline water temperature to almost saturated temperature and saline water in the basin needed only small heat to be vaporized and hence increases the production of fresh water and enhances the solar still thermal efficiency. Three types of still basin bottom surface were tested: flat, finned and corrugated. The finned surface was found to give the best performance. Using finned surface can increase the fresh water production by $20 \%$. The effect of using a solar heating system was also investigated and found to enhance the still performance significantly

\section{References}

[1] A.S. Nafey, M. Abdelkader, A. Abdelmotalib and A.A. Mabrouk, "Parameters affecting solar still productivity", Energy Conversion \& Management, 41, pp. 1797-1809.

[2] H.N. Singh and G.N. Tiwari; "Monthly performance of passive and active solar stills for different Indian climatic conditions", Desalination, 168, pp. 145-150.

[3] D.W. Medugu and L.G. Ndatuwong, "Theoretical analysis of water distillation using solar still", International Journal of Physical Sciences, 4(11), pp. 705-712.

[4] S.M. Radwan, A.A. Hassanin and M.A. Abu-zeid, "Single slope solar still for sea water distillation", World Applied Sciences Journal, 7(4), pp. 485-497.

[5] T.V. Arjuna1, H.Ş. Aybar and N. Nedunchezhian, "A study on effects of water capacity on the performance of a simple solar still", International Journal of Applied Engineering Research, 4(11), pp. 2223-2234.

[6] Masoud Afrand, Amin Behzadmehr, Arash Karimipour, "A Numerical simulation of solar distillation for installation in Chabahar-Iran", World Academy of Science, Engineering and Technology, 47, pp. 469-474.

[7] P. Rajendra Prasad, Padma Pujitha, B., G. Venkata Rajeev and K.Vikky, "Energy efficient solar water still", International Journal of ChemTech Research, 3(4), pp. 1781-1787. 